\title{
GLACIOLOGICAL PROBLEMS SET BY THE CONTROL OF DANGEROUS LAKES IN CORDILLERA BLANCA, PERU. III. STUDY OF MORAINES AND MASS BALANCES AT SAFUNA
}

\author{
By Louis Lliboutry, \\ (Laboratoire de Glaciologie du CNRS, Grenoble, France) \\ Benjamín Morales Arnao \\ (Instituto de Geología y Minería, Lima, Peru) \\ and Bernard Schneider \\ (Coyne et Bellier, Paris, France)
}

\begin{abstract}
We explain how preliminary results concerning the internal constitution of the big push moraine at Safuna were obtained in 1967 . Cross-sections which were obtained later through electrical and seismic exploration and arduous borings are given. Under the lake Safuna Alta there exists a layer of dead ice which is probably a remnant from an old glacier advance and over which the active glacier slides, but this dead ice does not extend into the push moraine. Since 1950 Safuna Alta has formed, the glacier tongue has lowered by $0.8 \mathrm{~m}$ per year on average, and the big push moraine has moved and settled.

The annual balance on the glacier tongue was measured in 1968 . It increases by $3.9 \mathrm{~m}$ of ice per $100 \mathrm{~m}$ in altitude. The discharge of ice near the lake and the annual balance further up-valley allow an estimate of the mean annual balance in the accumulation zone (between 4850 and $6020 \mathrm{~m}$ ) at $2.30 \mathrm{~m}$ of water per year. Until now no annual precipitation higher than $1 \mathrm{~m} /$ year had been measured in Cordillera Blanca, but this Cordillera includes many meso-climates.

Eight successive moraines are found at Safuna. They are tentatively correlated with the eight existing between Huaraz and Laguna Llaca. Clapperton's (1972) "group 4" was not formed during the 20th, but during the 17 th century. His "group 3" is not from A.D. 1750-180o, but is rather 5000 to 7 ooo years old, according to the offset of Cordillera Blanca great fault.
\end{abstract}

Résumé. Problèmes glaciologiques soulevés par le contrôle de lacs dangereux de la Cordillera Blanca, Pérou. III. Étude des moraines et des bilans de masse à Safuna. Après avoir indiqué comment furent obtenus en 1967 de premiers résultats sur la constitution interne de la grande moraine de poussée de Safuna, on en donne des coupes obtenues ensuite par prospection électrique et sismique, ainsi qu'à l'aide de laborieux forages. Sous le lac Safuna Alta se trouve une masse de glace morte qui est probablement le résidu d'une ancienne avance du glacier et sur laquelle glisse le glacier actif, mais cette glace morte ne se prolonge pas sous la moraine. Depuis r950, Safuna Alta s'est formée, la langue du glacier a baissé de niveau au taux moyen de o,8 m/an, et la grande moraine de poussée s'est déplacée et tassée.

Le bilan annuel sur la langue a été déterminé en 1968 . Il augmente de 3,9 $\mathrm{m}$ de glace pour $100 \mathrm{~m}$ d'altitude. Le débit de glace à proximité du lac et le bilan annuel plus en amont permettent d'évaluer le bilan moyen dans la zone d'accumulation (entre $4850 \mathrm{~m}$ et $6020 \mathrm{~m}$ ) à $2,30 \mathrm{~m}$ d'eau par an. Jusqu'ici on n'avait pas mesuré de précipitations moyennes annuelles supérieures à $1 \mathrm{~m}$ dans la Cordillera Blanca, mais elle comporte de nombreux mésoclimats.

On trouve huit moraines d'âges successifs à Safuna, qu'on tente de corréler aux huit moraines existant entre Huaraz et la Laguna Llaca. Le "groupe 4" de Clapperton (1972) ne s'est pas formé au 20e siècle, mais depuis le 17 e. Son "groupe 3" ne date pas de $1750-1800$ ap. J.-C., mais d'il y a 5000 à 7 ooo ans, à en juger par le jeu de la grande faille de la Cordillera Blanca.

Zusammenfassung. Glaziologische Probleme bei der Kontrolle gefährlicher Seen in der Cordillera Blanca von Perú. III. Moränen- und Massenhaushaltsstudien am Safuna. Es wird eine Erklärung für die vorläufigen Ergebnisse von I 967 über die innere Struktur der grossen Stauchmoräne am Safuna gegeben. Querprofile, die später durch elektrische und seismische Messungen sowie durch schwierige Bohrungen gewonnen wurden, werden wiedergegeben. Unter dem Safuna-Alta-See liegt eine Schicht von Toteis, das vermutlich ein Überrest eines alten Gletschervorstosses ist und über das der aktive Gletscher gleitet; doch setzt sich dieses Toteis nicht in die Stauchmoräne fort. Seit der Bildung von Safuna Alta im Jahre 1950 ist die Gletscherzunge pro Jahr im Mittel um o,8 m eingesunken und die grosse Stauchmoräne hat sich verlagert und konsolidiert.

Der jährliche Haushalt der Gletscherzunge wurde 1968 gemessen. Er nimmt auf roo m Höhenunterschied um 3,9 $\mathrm{m}$ Eis zu. Der Eisausstoss nahe am See und der Jahreshaushalt weiter oben gestatten eine Schätzung des mittleren jährlichen Haushalts in der Akkumulationszone (zwischen 4850 und 6 o20 m) auf $2,30 \mathrm{~m}$ Wasser. Bisher wurde in der Cordillera Blanca kein Jahresniederschlag höher als $1 \mathrm{~m}$ gemessen, aber sie besitzt viele klimatische Zwischenzonen.

Am Safuna wurde eine Folge von 8 Moränen gefunden. Versuchsweise wurden sie den 8 Moränen zwischen Huaraz und der Laguna Llaca zugeordnet. Clappertons (1972) "Gruppe 4" wurde nicht im 20. sondern im 17. Jahrhundert gebildet. Seine "Gruppe 3" stammt nicht von 1750-180o n. Chr., sondern ist eher 5000 bis 7000 Jahre alt, entsprechend der Bildung der grossen Verwerfund in der Cordillera Blanca. 


\section{INTRODUGTION}

The first glaciological work in Cordillera Blanca was done between r967 and r969 on the glacier which flows from Pucahirca $(6020 \mathrm{~m}$, at the north-east extremity of the Cordillera) towards the north-north-west and which will be called "Glaciar Safuna" (see map, fig. 2, in Lliboutry and others (1977)). Safuna is in fact the name of a lake dammed by old moraines a little down-valley (Fig. I). When, after I950, a new lake appeared on the glacier tongue (Fig. 2), the older lake became Laguna Safuna Baja and the new one Laguna Safuna Alta. Both lakes have no visible outlet, and keep their level (4 245 and $4363 \mathrm{~m}$ respectively) through infiltrations (cf. map, Fig. 3). It has been reported in Lliboutry and others (1977) how Safuna Alta emptied after the 1970 earthquake.

The goal of the glaciological work was to ascertain the depth of the rock basement, the internal constitution of the main moraine, and the limits of glacier ice around and below dangerous Laguna Safuna Alta. In order to show how such a problem of applied glaciology was handled, it will be reported chronologically. Nevertheless, in the course of this, another result was obtained: an estimate of the average precipitation in the highest corries of Cordillera Blanca. This datum is essential for any modern hydroelectrical equipment in this Cordillera. Lastly, the characteristics of the glaciation so found must be kept in mind when studying Holocene glacier fluctuations, a broad topic that we can only touch upon briefly here.

\section{Preliminary study of Safuna, i i-i 9 July i 967}

First observations by MM Pautre and Post (of Coyne et Bellier engineering office) and the authors took place in July 1967 . To reach the site from the Santa valley, a car journey to Pomabamba and a further journey on horseback are needed.

First the lake was sounded with a plumb line, along a line crossing the lake marked by a nylon cord supported by fishing-net floats. The sounding was done from a small rubber boat and since the lake surface froze each night, we attempted to protect the rubber boat with a wooden bow to convert it into an icebreaker!

Simultaneously water temperatures at different depths were measured with a Telemac vibrating string. The upper layer reached $6^{\circ} \mathrm{C}$ at sunrise and $10^{\circ} \mathrm{C}$ in the late afternoon. The lake below was found to be very isothermal, at $\mathrm{I} . \mathrm{I} \pm 0.2^{\circ} \mathrm{C}$, with the exception of the deepest layer $\left(0.6^{\circ} \mathrm{C}\right)$. The only explanation was that glacier ice underlies the lake.

The springs at the foot of the moraine were at $\mathrm{I} . \mathrm{I}^{\circ} \mathrm{C}$ on the right-hand side, denoting lake water, but at $0.3^{\circ} \mathrm{C}$ on the left side, denoting water which had flowed through ice.

A superficial examination of the moraines showed the existence of a faint inner recent moraine still lying over the glacier on the left side (moraine VI on the map). It may be attributed to the $1920-27$ glacier advance, assuming that this advance, recorded elsewhere in Cordillera Blanca (cf. Lliboutry and others, I977), has been general in the area. Thus the big moraine damming the lake (moraine $\mathrm{V}$ on the map) is at least one century old. On the left bank a cliff of ice showed a basal moving moraine (sheared strata of ice and earth) parallel to the steep inner slope of moraine $\mathrm{V}$. Thus this huge moraine is a rather old push moraine, and it was provisionally concluded that it does not enclose any big ice core.

Lastly the glacier tongue was examined. There were at least five moulins. This, and the fact that the mean air temperature of the site is about $5^{\circ} \mathrm{C}$, allowed us to assert that the glacier tongue is temperate.

The displacement of eighteen paint marks on boulders during $3 \mathrm{~d}$ gave an idea of the velocities: they increase from the front upwards from 5.6 to $77 \mathrm{~m}$ per year. If there was no sliding, a thickness increasing from 120 to $230 \mathrm{~m}$ could be inferred. On the other hand, since the friction on the bedrock $\tau_{\mathrm{b}}$ rarely exceeds $\mathrm{I} .5$ bar, and the glacier slope $(\tan \alpha)$ is at least 


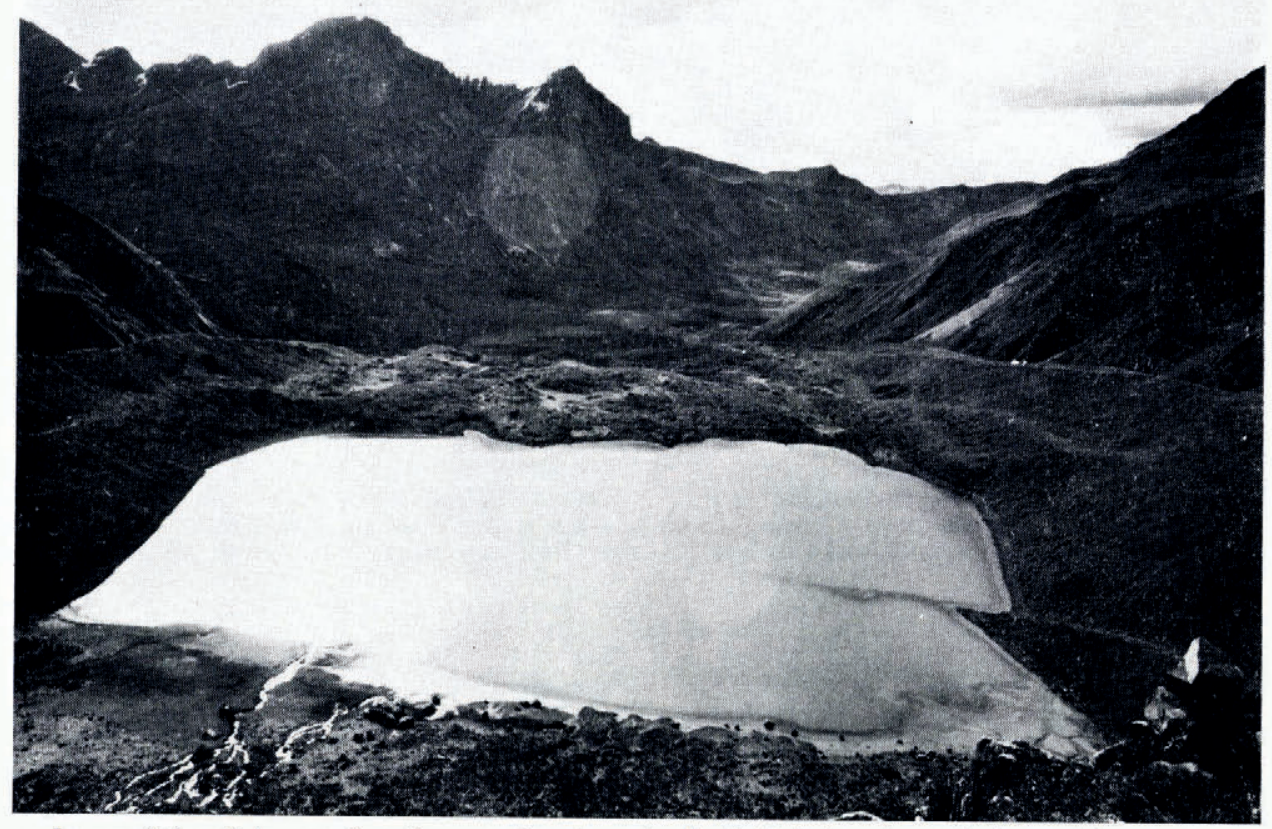

Fig. 1. Laguna Safuna Baja, seen from the crest of push moraine V. Behind the cairn at the lower right corner, moraine III which crosses the lake. Around the lake, moraines II and I. At the bend of the valley, Huilcapampa lateral moraine. Oiz the opposite side, in the distance the still older "upper terrace".

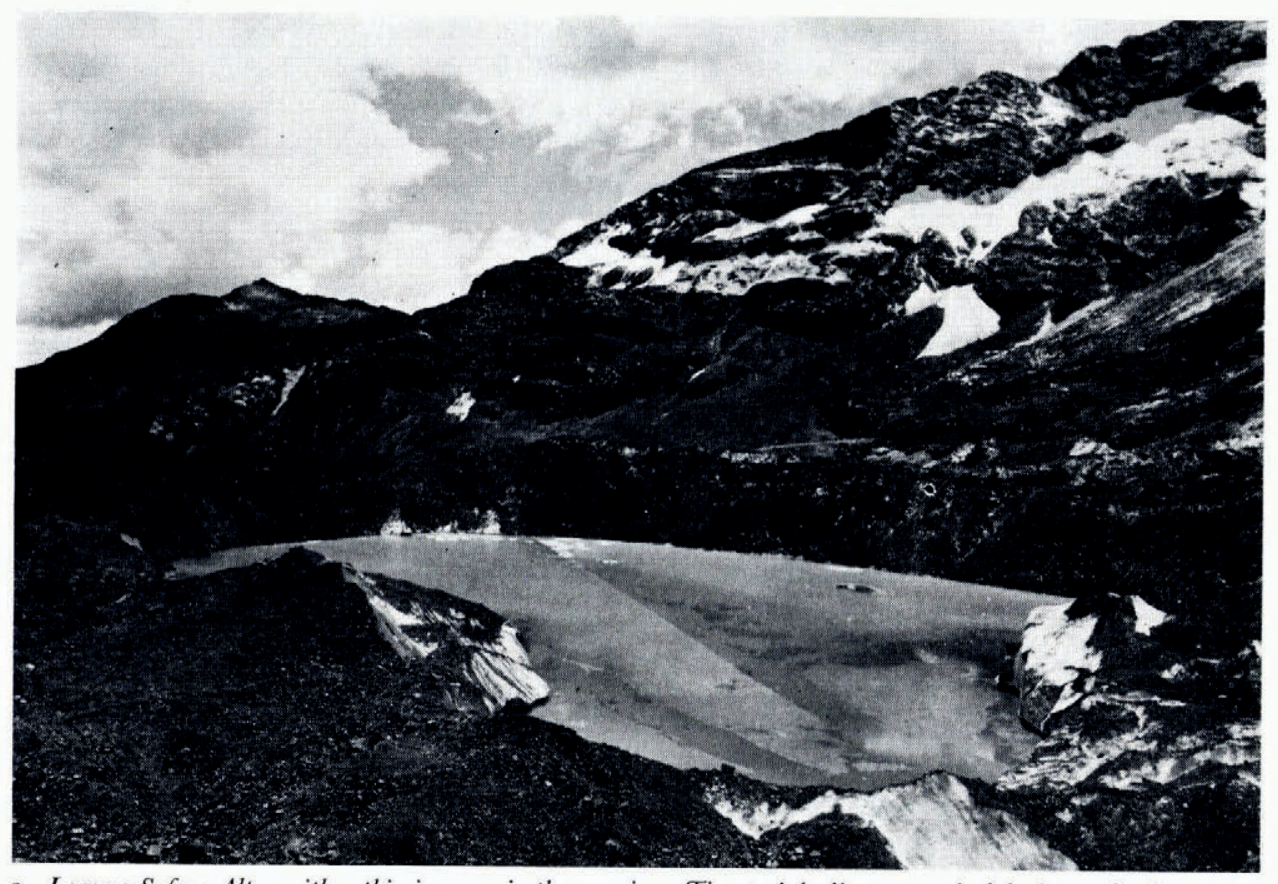

Fig. 2. Laguna Safuna Alta, with a thin ice cover in the morning. The straight line across the lake is a nylon line supported by fishing-net floats. Along it, in the middle of the lake, the small rubber boat used for hand sounding in 1967 can be seen. 


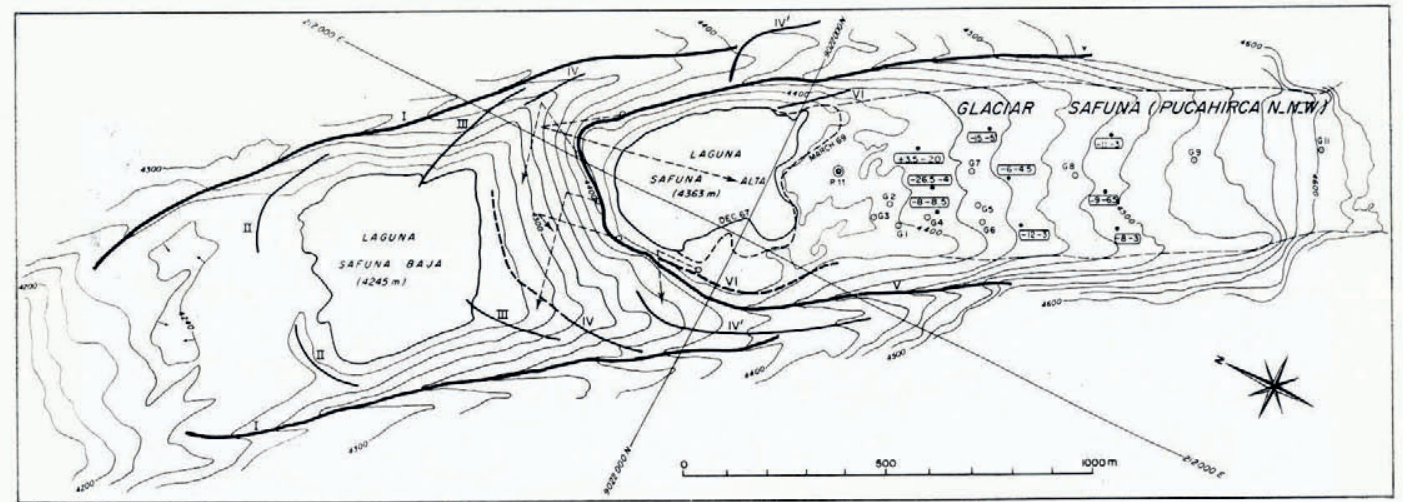

Fig. 3. Glaciar Safuna tongue and Safuna moraines $I$ to VI. $G_{I}$ to $G_{I I}=$ ablation stakes. $P_{I I}=$ site of drilling. Numbers in a box = lowering in metres, $1950-63$ and $1963-68$, at points of fixed coordinates (black dots). Dashed arrows $=$ movement of the crest of the moraine during the same intervals of time, exaggerated $25 \times$. (From aerial coverage specially plotted by S.A.N.)

o. Io, the glacier thickness $h$ cannot exceed $170 \mathrm{~m}$, according to the approximate classical relation

$$
\tau_{\mathrm{b}}=\rho g h \sin \alpha,
$$

where $\rho g$ is the specific weight of ice.

Thus we estimated the glacier thickness to be $150 \pm 20 \mathrm{~m}$, and concluded that there should be at the bottom of the lake about $50 \pm 20 \mathrm{~m}$ of ice. These preliminary estimations were sent to Peru in August I967 (Coyne et Bellier, Géoconseil, unpublished [b]), together with instructions about the geophysical explorations, borings, and surveys to be done.

On 17 October 1968 , at $13.3^{\circ} \mathrm{h}$, people observed the fall of 200 to $300 \mathrm{~m}^{3}$ of ice from the frontal glacier cliff into the lake, as already observed several times. Nevertheless this time, Io min after the ice fall, growlers of $5^{\circ}$ to $100 \mathrm{~m}^{3}$ began to emerge from the bottom of the lake. This process was seen going on until night. The following morning 150000 to $200000 \mathrm{~m}^{3}$ of icebergs, growlers and bergy bits were floating on the lake.

\section{GEOPHYSICAL EXPLORATION AND BORINGS}

From July 1967 to July 1969 one of us (B.S.) remained in the Santa valley to supervise the workings at Safuna and Parón. He made better soundings of the lake with an ultrasonic echo-sounder, Rayton DE 707, sold for fishing purposes. The appearance of the records allows us to distinguish whether the bottom is rock, moraine, or ice. Moreover since its beam is only $15-20^{\circ}$ wide, it can be directed horizontally to obtain the profiles of the ice cliffs below water level (Schneider, I969).

Under contract of CPS, Ing. José Arce made several geophysical explorations in December I967 and I968 (Arce, unpublished; Coyne et Bellier, Géoconseil, unpublished [a]).

Seismic soundings were made with a line of twelve geophones, $20 \mathrm{~m}$ apart, a GT 2 amplifier, and a Polaroid recorder. On the glacier tongue six reflexion profiles, parallel to the glacier bank, were shot. They gave poor reflexions, probably because of a morainic layer with boulders and subglacial cavities. The thickness at the cross-section B (Fig. 4) was everywhere found to be about $\mathrm{i} 80 \mathrm{~m}$.

In the moraine this equipment only allows echoes to be obtained when the reflector is less than $80 \mathrm{~m}$ deep. This was the case only on the sides of the valley. The refraction techniques gave $P$-wave velocities between I $530 \mathrm{~m}$ and I $900 \mathrm{~m} / \mathrm{s}$. Although moraines I and II (damming Safuna Baja) and the lower part of moraine V (damming Safuna Alta) have similar 

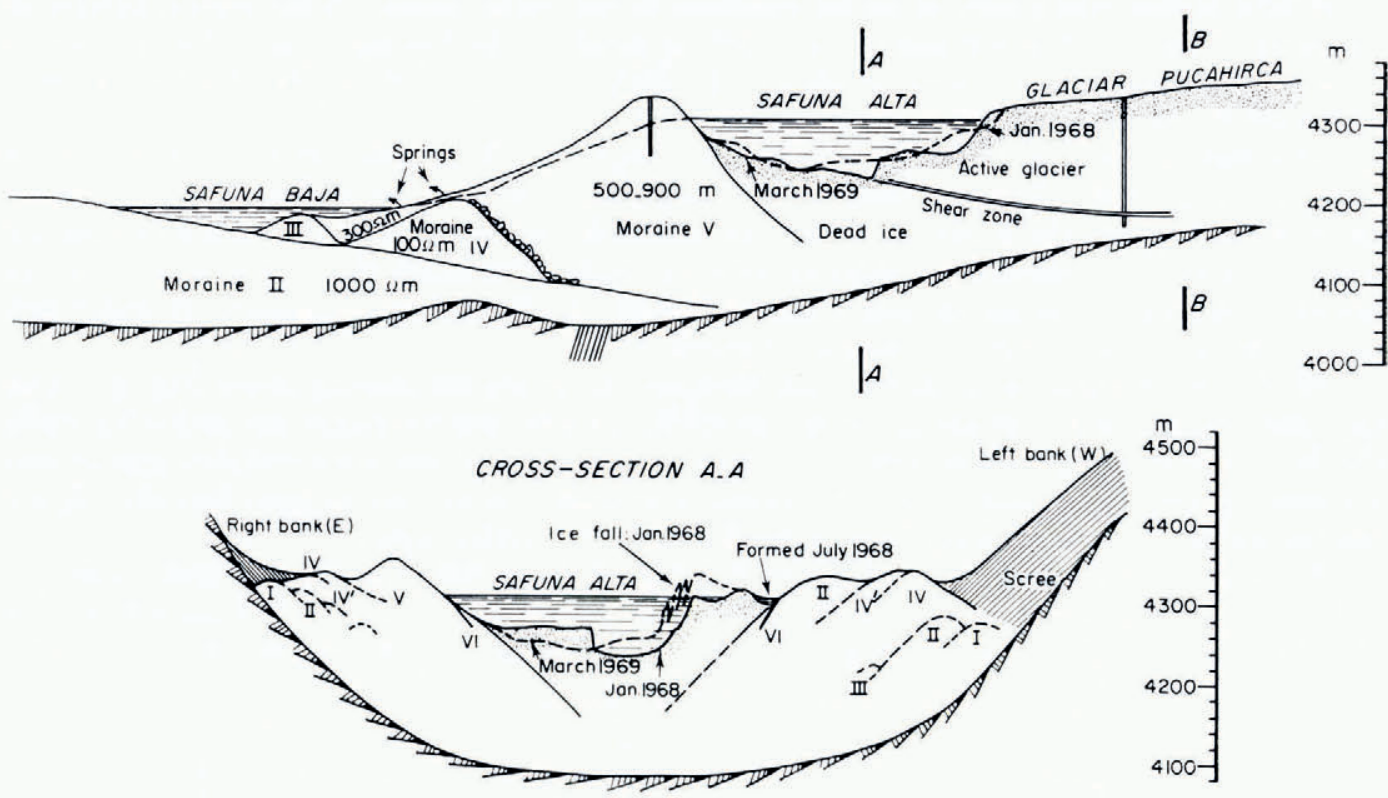

Fig. 4. Cross-sections as determined by seismic and electrical exploration and by borings.

high velocities (I $850 \mathrm{cf}$. I $880 \mathrm{~m} / \mathrm{s}$ ), the frequency of the first waves was quite different $(40 \mathrm{~Hz}$ cf. $106 \mathrm{~Hz})$. According to Arce this indicates that moraines I-II are substantially less compact, and have high $P$-wave velocities only because they are extensively water-saturated. This seems to indicate that moraines I-II are ablation moraines never compacted by glacier pushing.

At the foot of push-moraine $\mathrm{V}$ and on its external slope, seven electrical d.c. profiles showed:

a water table 5 to i I m deep,

a top layer with a resistivity of $100 \Omega \mathrm{m}$,

a second layer with a resistivity of I ooo $\Omega \mathrm{m}$, attributed to a buried moraine IV, visible on both sides of moraine $\mathrm{V}$,

a deep layer with infinite resistivity, thought to be the rock basement. Thus no ice core was identified within the moraine.

Seven borings were made from September 1967 to December 1968 by Jacobs Plücker Brothers. A rotary drill $\mathrm{B}_{5} \mathrm{I}$ of Boyler Bros Drilling Co Ltd with a tricone head was used.

Two borings were made at the foot of push-moraine $\mathrm{V}$, to $4 \mathrm{I} .8$ and $35.7 \mathrm{~m}$ respectively. The first one, which lasted two and a half months, was done on the axis of the valley. Under $5.5 \mathrm{~m}$ of pervious moraine, a $15 \mathrm{~m}$ thick layer of very impervious lacustrine sediments was found, overlying clayish dark moraine without big boulders, with lenses of impervious clay. The lacustrine sediments layer was not found on the right bank.

Two other borings were performed on the crest of push moraine V. Depths of 38.4 and $82.6 \mathrm{~m}$ respectively were reached with considerable effort, without finding any ice core: only sand, clay, pebbles, boulders of quartzitic shale up to I $\mathrm{m}$ thick. The first boring lasted six months. The bore holes were cased down to 23 and $52 \mathrm{~m}$ respectively, and then grouted. $\mathrm{Up}$ to $6 \mathrm{o} \mathrm{kg}$ of dry cement per metre of perforation, 2 r oo $\mathrm{kg}$ of cement in total, were needed! 
A fifth boring was made on an ice remnant at the right corner. After several metres of morainic cover, bubbly soft glacier ice, getting hard at the bottom, was found for $10 \mathrm{~m}$. Next the drill emerged into a cavity about $\mathrm{I} m$ thick at the ice-moraine interface, which was half infilled with loose debris.

The final boring was done on the glacier tongue itself, at point PII, in $60 \mathrm{~h}$, almost without interruption. Between depths of 135 and $13^{8} \mathrm{~m}$ the drill met a sheared zone with an internal crack $20 \mathrm{~cm}$ thick through which the bore hole lost its water. Underneath this the ice was harder and contained small angular debris of shale. Obviously the active glacier is there superimposed on old dead ice and slides on it with the formation of cavities. Drilling had to be interrupted at $\mathrm{I} 55 \mathrm{~m}$ because bars twisted.

All this work allows us to sketch with adequate accuracy the cross-sections (Fig. 4). The fact that near the lake only about $\mathrm{I} 38 \mathrm{~m}$ out of $\mathrm{I} 80 \mathrm{~m}$ of the glacier tongue are active has been checked by an estimation of the difference in the ice discharge at two cross-sections, taking into account the measured balances and assuming a stationary state. We suggest that the big ice emergence of I $_{7}$ October 1968 came from the tip of the active layer.

Nevertheless we cannot say whether the sheared zone has formed as a fault within a previously homogeneous active glacier, or by the superimposition of an advancing glacier over an old mass of dead ice. We incline towards the later process, which was observed by

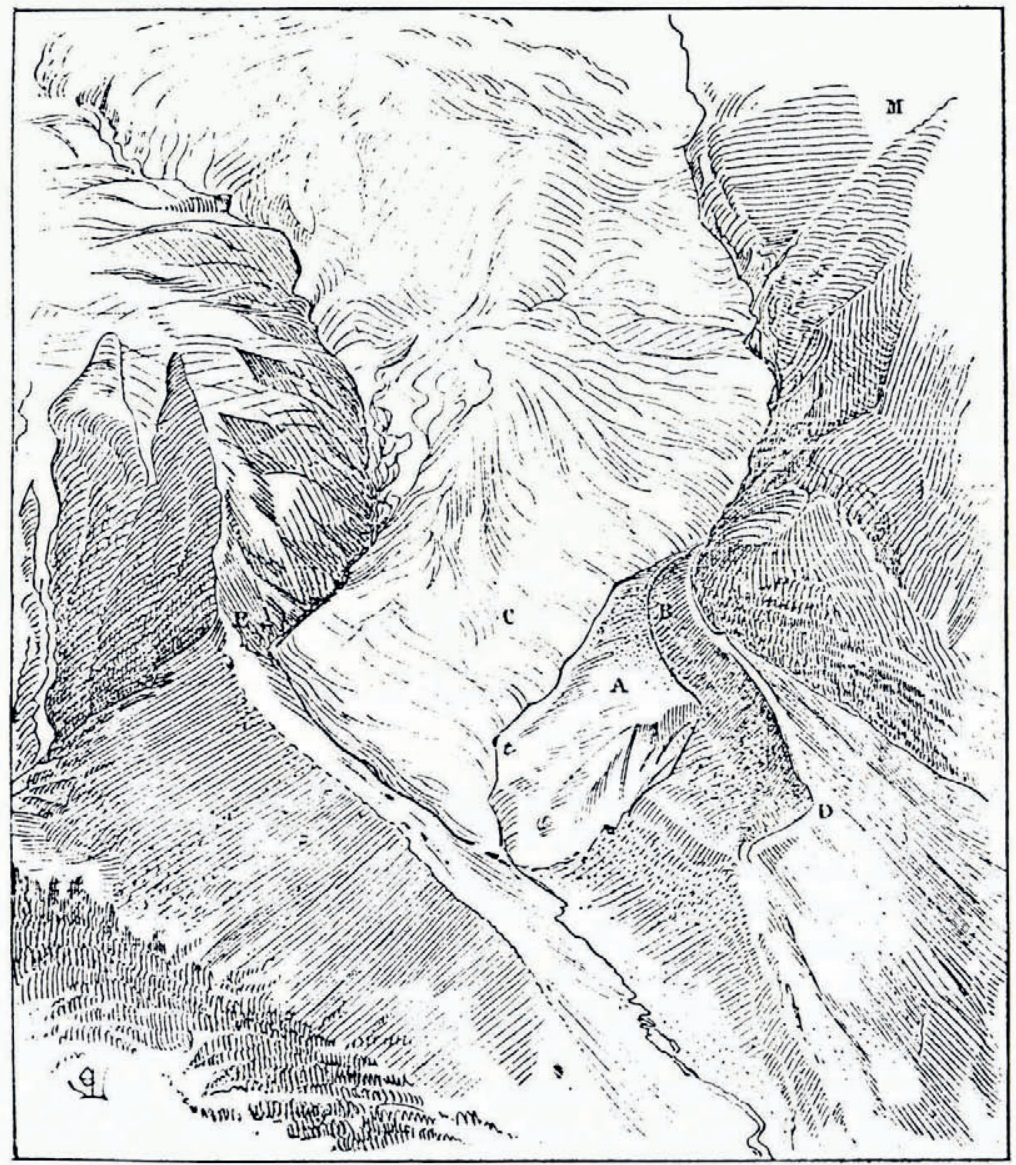

Fig. 5. Tongue of Glacier des Bossons (north slope of Mont Blanc, French Alps) sketched by Viollet-le-Duc in I873. The active tongue $C$ from the 1835 advance was superimposed on dead ice $A$ left by the 1770 advance. 
Viollet-le-Duc (1876) at Glacier des Bossons (French Alps). His sketch, which is reproduced as Figure 5, gives the situation in July $\mathrm{r} 873$. The glacier tongue $\mathrm{C}$, which in 1835 almost reached the road to Chamonix on the opposite side of the valley had been receding since then. It had left uncovered a mass of ice A remaining from the I 770 advance. Both ice masses were separated by a debris layer and, although they were fused together enough to allow a streamlet at the junction, Viollet-le-Duc concludes from the morphology that the old ice mass was not dragged down consistently by the superimposed glacier tongue.

\section{MOVEMENTS OF THE PUSH MORAINE V}

An accurate plotting of the aerial coverages of 1950 , I963 and 1968 has been done by SAN (Servicio Aerofotográfico Nacional). It allows us to assert that the big push moraine V has significantly moved between these dates. The displacement of five big boulders emerging at the crest of the moraine are given on the map (Fig. 3). The accuracy is about $\mathrm{I} \mathrm{m}$ for the horizontal positions and $0.5 \mathrm{~m}$ for the vertical ones.

Twenty-four stakes put on the crest of moraine $\mathrm{V}$ were surveyed five times in 1968 from two points on firm rock, on the two sides of the valley, I $400 \mathrm{~m}$ apart. The disposition optimized the accuracy, but it is known that near a mountain glacier horizontal deviations of the lines of sight up to 0.005 grades may occur (Reynaud, 1975). Thus the accuracy of the position of the stakes should be $\pm 5 \mathrm{~cm}$. Nevertheless the displacements were significant.

Between $195^{\circ}$ and 1963 , the front moraine moved forward by 3 to $8 \mathrm{~m}$. Between ${ }_{9} 63$ and I 968 , it moved by a similar amount, with the exception of the right (northern) corner, which moved towards the lake, up-valley. Similar velocities ( 0.2 to $0.4 \mathrm{~m} /$ year) were found in 1968 . Where the push moraine is in contact with the glacier, it moves outwards, radially. Where it is in contact with the lake, it moves in the opposite direction, towards the lake.

As shown by Table I, the settling of the crest has, on average, increased with time, and most of it happens during the rainy season. Let us recall that the 1970 earthquake settled the moraine by $1.0 \mathrm{~m}$ (Lliboutry and others, 1977).

\begin{tabular}{|c|c|c|}
\hline & Number of points averaged & Vertical downward velocity \\
\hline $\begin{array}{l}93^{\circ} \\
1963\end{array}$ & 5 & $7.7 \mathrm{~cm} /$ year \\
\hline I968 & 5 & $22.0 \mathrm{~cm} /$ year \\
\hline $\begin{array}{l}\text { 22 January I } 968 \\
\text { (rainy season) } \\
22 \text { April I } 968\end{array}$ & 17 & $14.7 \mathrm{~cm} /$ month \\
\hline $\begin{array}{l}\text { (dry season) } \\
\text { 22 June I } 968\end{array}$ & 15 & $3.7 \mathrm{~cm} /$ month \\
\hline $\begin{array}{l}\text { (dry season) } \\
23 \text { September }{ }_{1968}\end{array}$ & 17 & $2.1 \mathrm{~cm} / \mathrm{month}$ \\
\hline
\end{tabular}

\section{Glacier Velocities and Balances}

The lowering of the surface of the glacier tongue at six points of fixed geographical coordinates for $\mathrm{I}_{95}-63$ and $\mathrm{i} 963^{-68}$ are given on Figure 3 . At $\mathrm{I} 250 \mathrm{~m}$ and at $\mathrm{i}$ ooo $\mathrm{m}$ from the crest of frontal moraine $\mathrm{V}$ the average lowering rate has been $0.8 \mathrm{~m} /$ year for both intervals of time. At $830 \mathrm{~m}$ from the crest it has been $0.8 \mathrm{~m} /$ year during the first, $2.7 \mathrm{~m} /$ year during the second.

Ten ablation stakes were surveyed four times in r968 (Ames, i969). The interval of time between the first and the last survey was $242 \mathrm{~d}$. Position of stakes is given on Figure 3 and the measured horizontal velocities on Table II. 
Table II. Surface velocities on the glacier tongue

\begin{tabular}{|c|c|c|c|c|}
\hline \multirow[t]{2}{*}{ Stake } & \multicolumn{2}{|r|}{ Dry season } & $\begin{array}{l}\text { Beginning of the } \\
\text { rainy season }\end{array}$ & Mean value \\
\hline & 22 April 1968 & 22 June $1968 \quad 23$ & mber 196820 December 1968 & \\
\hline GI $_{1}$ & $\mathrm{~cm} / \mathrm{d}$ & $\mathrm{cm} / \mathrm{d}$ & $\mathrm{cm} / \mathrm{d}$ & $\mathrm{m} /$ year \\
\hline G2 & II.I & $\begin{array}{l}\text { I1.6 } \\
11.8\end{array}$ & 10.9 & $\begin{array}{l}41.2 \\
45.6\end{array}$ \\
\hline $\mathrm{G}_{3}$ & $\overline{12.7}$ & $\begin{array}{l}11.8 \\
10.9\end{array}$ & 13.4 & $\begin{array}{l}45 \cdot 6 \\
43.5\end{array}$ \\
\hline $\mathrm{G}_{4}$ & 15.2 & 13.8 & 14.3 & $\begin{array}{l}43.3 \\
52.3\end{array}$ \\
\hline $\mathrm{G}_{5}$ & 17.5 & 19.1 & 17.2 & 65.7 \\
\hline G6 & 19.1 & 18.6 & 17.2 & 66.6 \\
\hline $\mathrm{G}_{7}$ & 18.2 & 19.5 & - & 70.9 \\
\hline G8́ & 24.5 & $23 \cdot 1$ & 20.7 & 82.4 \\
\hline G9 & 30.7 & 32.2 & 31.0 & 114.5 \\
\hline GiI & 46.4 & & $4 \cdot 7$ & 165.0 \\
\hline
\end{tabular}

The seasonal fluctuations of velocity are erratic. On average they do not increase when the rainy season begins.

The discharge of ice may be calculated through cross-section $\mathrm{G}_{5}-\mathrm{G}_{6}-\mathrm{G}_{7}$ which is $400 \mathrm{~m}$ wide, $180 \mathrm{~m}$ deep. The axial velocity there is $u_{0}=70.9 \mathrm{~m} /$ year and the surface slope $\tan \alpha=1 / 5.5$. With the notation of Lliboutry (1977), $V=32.0 \mathrm{~m} /$ year, $W=200 / 180$, cve $(W)=0.802$ and ave $(W)=0.533$. With the assumptions of Lliboutry (1977), the average sliding velocity at this cross-section is $45.3 \mathrm{~m} /$ year and the discharge of ice $3.56 \times 10^{6}$ $\mathrm{m}^{3} /$ year.

Measured balances are given in Table III. A surprising fact is that they are more negative during the rainy season, although there is less insolation. The reader must keep in mind that the seasonal fluctuations of air temperature are quite small in Peru, and thus in the ablation area rain is more frequent than snow. Now it is well known that ablation is very high during warm rain: to the sensible heat of rain must be added the latent heat of moist air dragged vertically by the drops.

Table III. Ablation rates on Glaciar Safuna (heights of ice)

\begin{tabular}{|c|c|c|c|c|c|}
\hline Stake & $\begin{array}{l}\text { Average } \\
\text { altitude } \\
\mathrm{m}\end{array}$ & I May $\begin{array}{r}1968 \stackrel{A}{2} \\
\mathrm{~cm} / \mathrm{c}\end{array}$ & $\begin{array}{l}\text { Average ablation rates } \\
25 \text { December } 196823 \text { April } 1969 \\
\mathrm{~d} \quad \mathrm{~cm} / \mathrm{d}\end{array}$ & $\begin{array}{l}\text { Total ablation } \\
\text { during } 35^{8} d \\
\mathrm{~m}\end{array}$ & $\begin{array}{l}\text { Annual } \\
\text { balance } \\
\mathrm{m} / \text { year }\end{array}$ \\
\hline $\mathrm{G}_{\mathbf{I}}$ & 4396 & 4.13 & $5 \cdot 3 \mathrm{I}$ & 16.19 & $\mathrm{I} 6.6$ \\
\hline $\mathrm{G}_{2}$ & 4393 & $4.2 \mathrm{I}$ & 5.73 & 16.90 & $17 \cdot 3$ \\
\hline $\mathrm{G}_{3}$ & 4388 & 4.16 & 5.73 & 16.77 & 17.2 \\
\hline $\mathrm{G}_{4}$ & 4405 & $4.1 \mathrm{I}$ & 5.96 & $16.9^{2}$ & 17.4 \\
\hline $\mathrm{G}_{5}$ & 4425 & 4.04 & 6.17 & 17.02 & 17.5 \\
\hline G 6 & 4424 & 4.40 & 5.23 & 16.75 & 17.1 \\
\hline $\mathrm{G}_{7}$ & 4424 & & & 16.00 & 16.4 \\
\hline G8 & 4475 & 4.23 & 5.13 & 16.22 & 16.6 \\
\hline G9 & 4530 & 2.87 & 4.19 & II .85 & 12.2 \\
\hline Gio & 4590 & & & 10.64 & 10.9 \\
\hline GII & 4599 & 2.08 & & & \\
\hline G12 & 4600 & & & $9 \cdot 33$ & 9.6 \\
\hline
\end{tabular}

The annual balance at $4400 \mathrm{~m}$ was found to be $-\mathrm{I} 7 \mathrm{~m}$ of ice (fifteen times more than on Hatunraju debris-covered glacier at the same altitude). As shown in Figure 6 its variation with altitude (the "activity coefficient") is very strong: $3.9 \mathrm{~m}$ of ice per I oo $\mathrm{m}$ of altitude. The equilibrium line is found at about $4850 \mathrm{~m}$ a.s.l. It should be the altitude where snowfalls turn into rain. This value is checked by the fact that in the same valley Nevado Pilanco has a glacier with a gentle slope facing west between 5080 and $4700 \mathrm{~m}$. At the same latitude in Cordillera Negra, Cerro Rocarre $(5 \mathrm{I} 87 \mathrm{~m})$ has no glaciers, and east of Río Marañon, Nevado Acrotambo $(4850 \mathrm{~m})$ is glacierized (Kinzl, I942). 


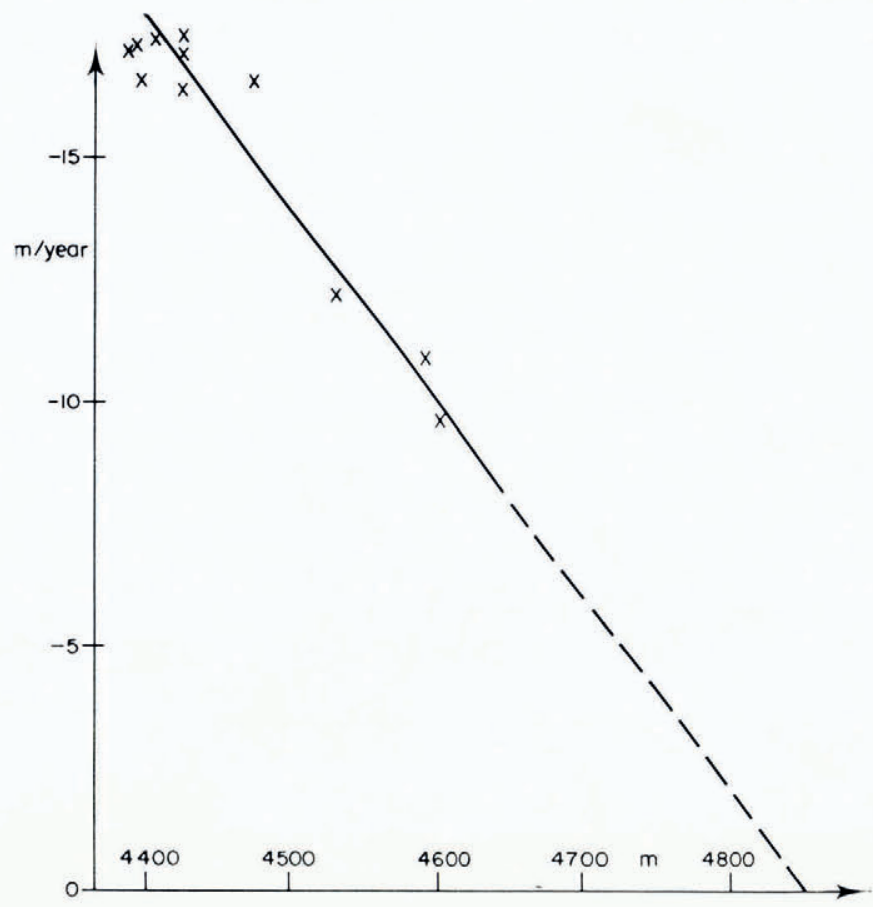

Fig. 6. Annual balance on Glaciar Safuna for 1968 as a function of altitude.

The SAN map at I : 25000 and the correlation of the balance with altitude have been found to lead to a total annual balance between the cross-section at $\mathrm{G}_{7}$ and the equilibrium line of $-6.0 \times 10^{6} \mathrm{~m}^{3}$ of ice per year. The lowering of the surface, about $0.8 \mathrm{~m}$ over $0.2 \mathrm{~km}^{2}$ gives only a corrective term. Since the discharge of ice at cross-section $\mathrm{G}_{7}$ equals $3.56 \times \mathrm{r}^{6}$ $\mathrm{m}^{3} /$ year, it follows that the total annual balance of the accumulation area must be about $9.4 \times 10^{6} \mathrm{~m}^{3}$ of ice per year.

The area of the accumulation zone being $3.62 \mathrm{~km}^{2}$, the average balance over it must be about $2.60 \mathrm{~m}$ of ice-equivalent $(2.30 \mathrm{~m}$ of water equivalent) per year. This value seems consistent with the discharge of springs at the foot of moraine $\mathrm{V}$, which has been monitored during two years: its mean value is about $370 \mathrm{l} / \mathrm{s}$, for a basin of $4.6 \mathrm{~km}^{2}$, giving a mean value of (precipitation plus condensation balance) equal to $2.54 \mathrm{~m}$ of water per year.

The ablation zone (not including the bottom of Laguna Safuna Alta) totals about $0.84 \mathrm{~km}^{2}$, and the average balance over it is about - I I $\mathrm{m}$ of ice per year. A correction must be made to take into account the calving into the lake, which was not estimated.

\section{Pregipitation and air temperature in Cordillera Blanca}

The amount of water collected in the basin of Glaciar Safuna, $2.5 \mathrm{~m} /$ year on average, may be compared to the $1.30 \mathrm{~m}$ of precipitation measured in 1968 at the new small meteorological station of Safuna (4 $350 \mathrm{~m}$ ), although 1968 was a rather dry year. The Safuna accumulation zone is a cirque limited by a ridge oscillating between 5560 and $6020 \mathrm{~m}$. Precipitation increases very much with altitude in Cordillera Blanca. Moreover the summits collect a great amount of rime, which gives them the peculiar aspect called feathered snow by alpinists (Fig. 7). 


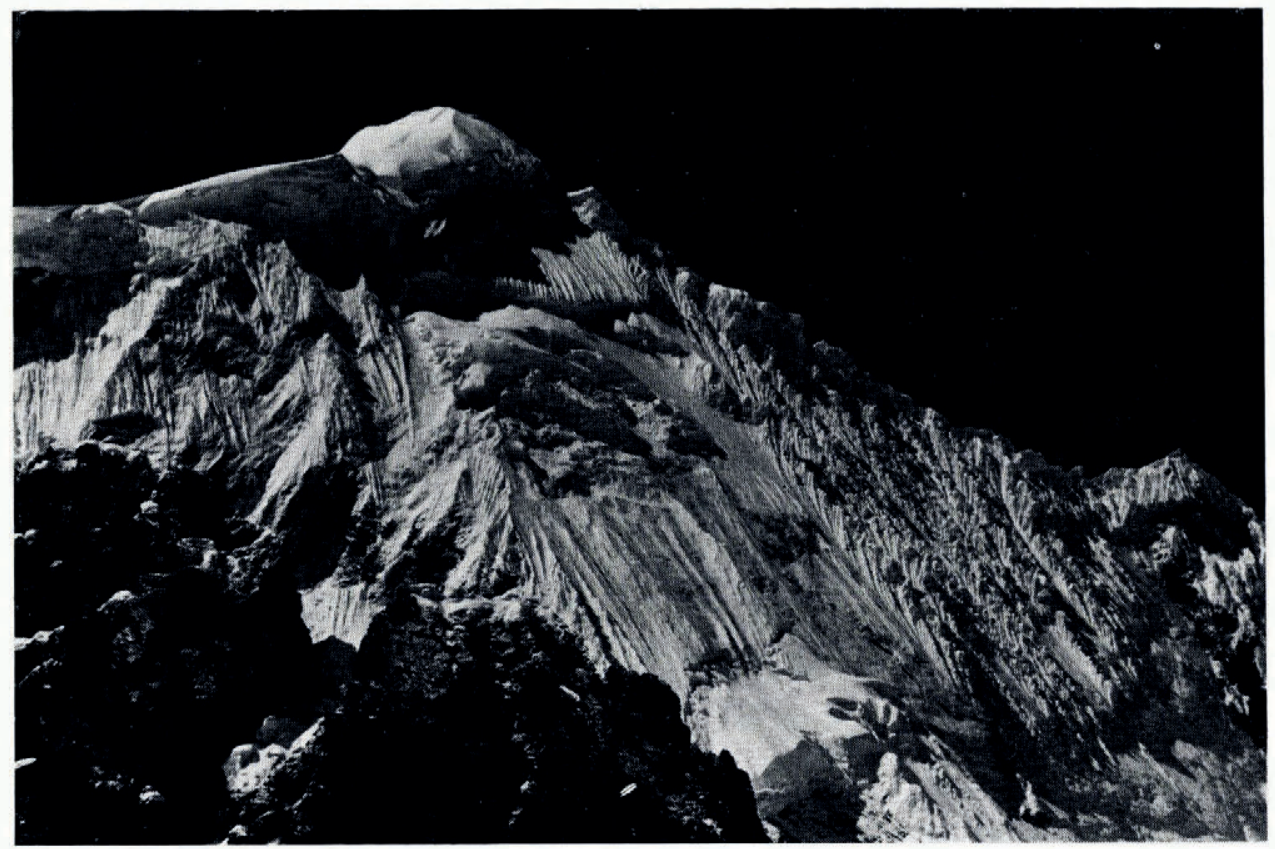

Fig. 7. Feathered snow at Pucahirca Norte $(6$ o2o m). Telephotograph from Safuna.

The difference from other pluviometric stations in the basin of Rio Santa is still more striking. Corporación Peruana del Santa (now Electroperú) operates a score of stations, the locations of which are given in Figure 8. The average annual precipitations during the fifteen years $1953-67$ are given in Table IV, and plotted against altitude in Figure 9. Safuna is much wetter than all the other locations, showing the influence of wet north-easterly winds blowing over $5000 \mathrm{~m}$.

Nevertheless all rain does not come from the north-east. During the rainy season, clouds at 4 300-5 $000 \mathrm{~m}$ coming from the south-west enter into the quebradas and cause rain most afternoons. This is the local up-valley wind commonly found in mountainous areas. We suggest that the same kind of local wind causes the rain at Ticapampa to be a maximum, when compared to other stations on Rio Santa.

The stations in the upper Santa valley (No. I to 5 ) have their precipitations well correlated together (empirical cross-correlation coefficients: 0.7 I I to 0.928). For the stations No. 6 to I I, on a transverse line, the cross-correlations are poorer (0.597 to $\left.0.8{ }_{1} 8\right)$. Stations No. 4 and 8 are the most representative of these two groups, and alone are considered in Table V. It shows that the fluctuations of the annual precipitation at the two stations within Cordillera Blanca (Parón and Llanganuco) show almost no correlation with the fluctuations in the Santa valley. Their mutual correlation also is rather insignificant.

Thus Cordillera Blanca and the Santa valley offer a fair diversity of mesoclimates. This can be noticed also by considering the histograms of monthly precipitations in Figure $\mathrm{I}$. We have classified them into two groups, according to whether there is a sharp maximum in March, or a broad one from January to March or April. Dry sites and wet ones, locations in the Cordillera and in the Santa valley, fall in each group in a random way.

Fig. 8 (opposite). Pluviometric stations of CPS in Rio Santa basin. Black = areas over 5 ooo $m . \quad I=$ crest of Cordillera Negra. $2=$ limit of visible batholith, coinciding approximately with the Cordillera Blanca great fault. 


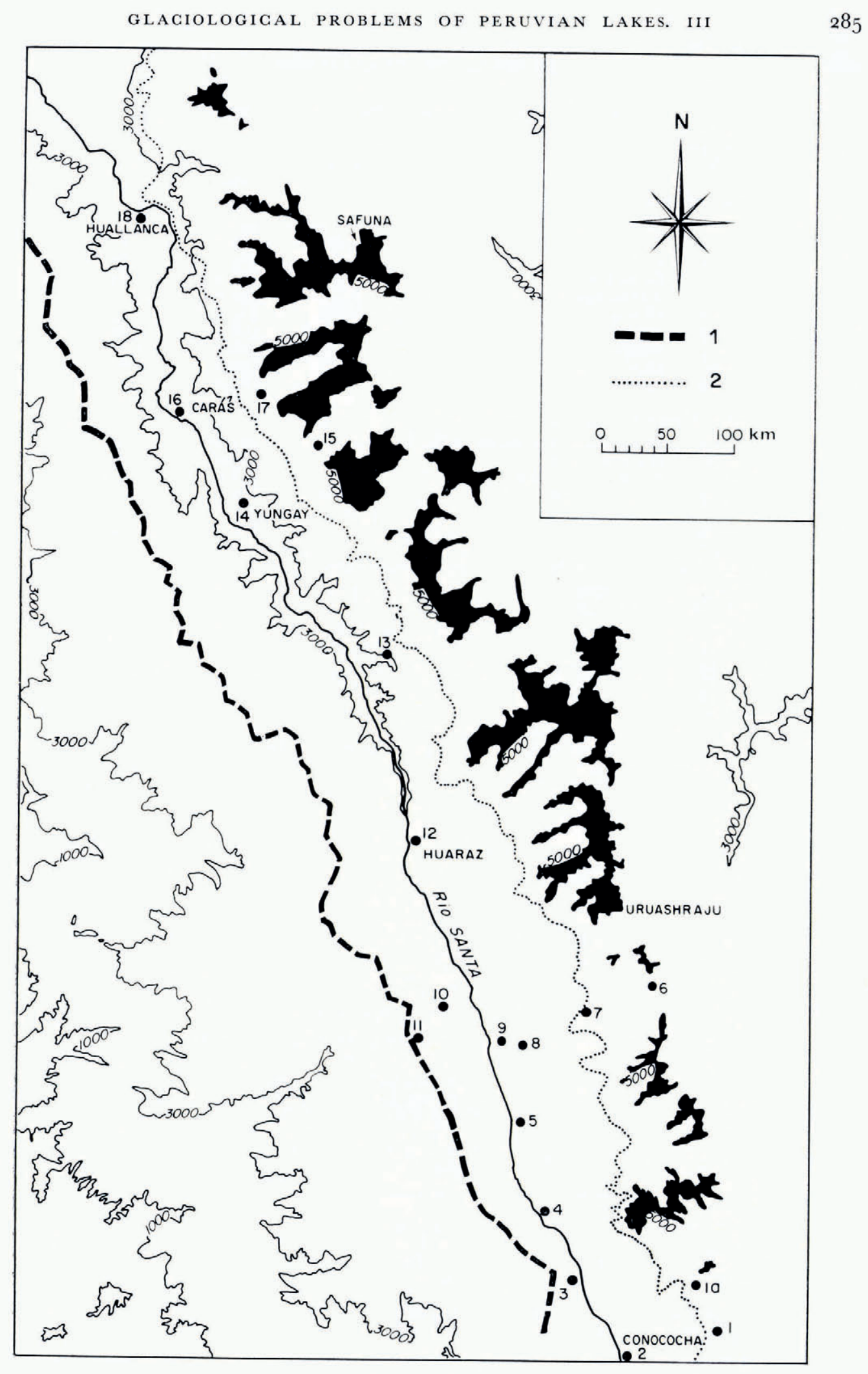

https://doi.org/10.3189/S0022143000021353 Published online by Cambridge University Press 
Table IV. Average annual precipitations $1953-67$

Station

(a) Along Rio Santa

$\begin{aligned} 2 & \text { Conococha } \\ 3 & \text { Recreta } \\ 4 & \text { Collota } \\ 5 & \text { Pachacoto } \\ 9 & \text { Ticapampa } \\ 12 & \text { Huaraz } \\ 13 & \text { Chancos } \\ 14 & \text { Yungay } \\ 16 & \text { Caraz } \\ 18 & \text { Hidroelectra(1) }\end{aligned}$

Name

b) Transverse line by lat. $9^{\circ} 45^{\prime} S$.

b) Transuerse line by lat. $g^{\circ} 45^{\prime} S$.

II Huancapeti (Cordillera Negra)(2)

Io Quiruncancha

9 Ticapampa (Rio Santa)

Shacaypampa

Querococha

Cahuish (Cordillera Blanca)

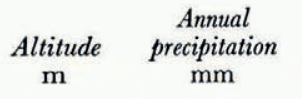

Standard

deviation

$\mathrm{mm}$

$\begin{array}{llr}4 \text { O20 } & 441.9 & \pm 133 \\ 3980 & 483.6 & \pm 100 \\ 3900 & 505.5 & \pm 169 \\ 3570 & 608.5 & \pm 184 \\ 3550 & 752.8 & \pm 101 \\ 3063 & 539.7 & \pm 154 \\ 3100 & 512.1 & \pm 101 \\ 2535 & 318.2 & \pm 84 \\ 2285 & 190.0 & \pm 68 \\ 1380 & 169.0 & \pm 45\end{array}$

(c) Nearby stations on Rio Santa and in Cordillera Blanca

\begin{tabular}{|c|c|c|c|c|}
\hline 2 & Conococha & 4020 & $44^{1} \cdot 9$ & \pm 133 \\
\hline ia & Yanacocha ${ }^{(2)}$ & 4500 & $935.0^{*}$ & \pm 182 \\
\hline I & Mojón & $44^{24}$ & 731.5 & \pm 190 \\
\hline 14 & Yungay ${ }^{(3)}$ & 2535 & 305.6 & \pm 88 \\
\hline 15 & Llanganuco(3) & 3850 & 708.6 & \pm 154 \\
\hline 16 & Caraz & 2285 & 190.0 & \pm 68 \\
\hline 17 & Parón & 4200 & 865.1 & \pm 162 \\
\hline
\end{tabular}

(1) $1954-67$; (2) $1955-67$; (3) $1956-67$.

* Estimated since r 953 thanks to the correlation of fluctuations with those of nearby stations.

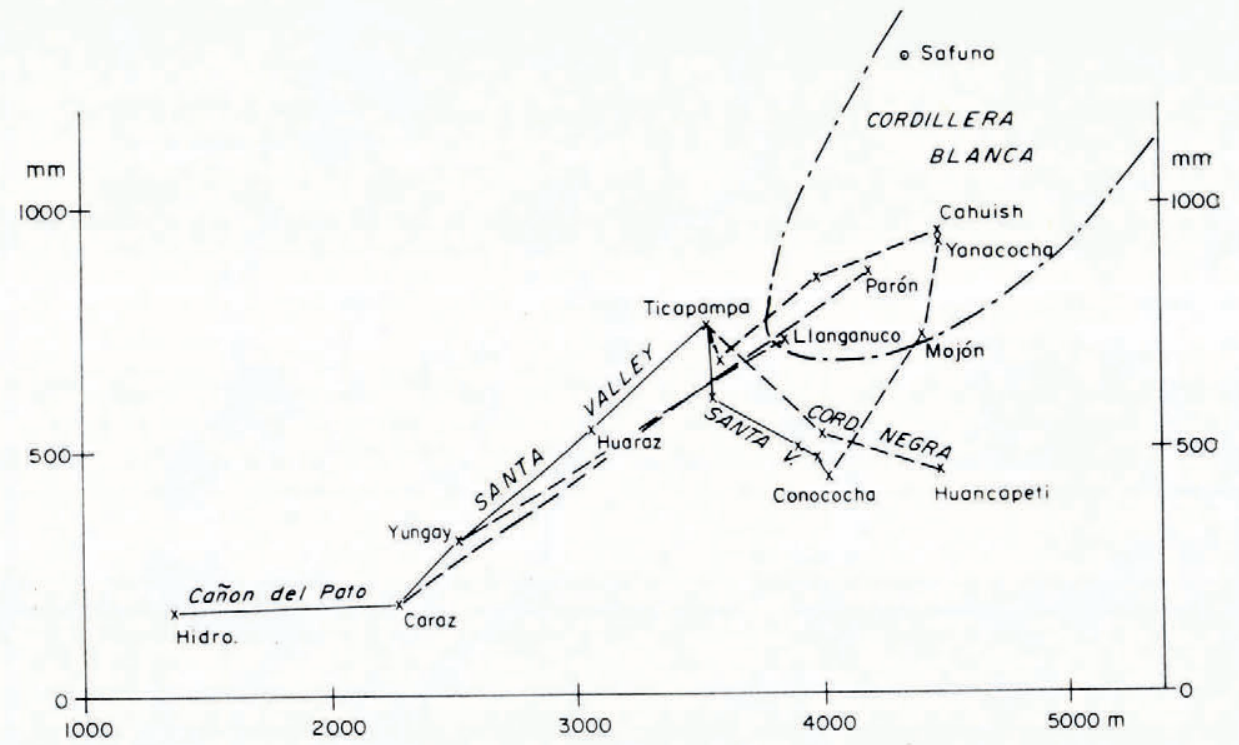

Fig. 9. Mean annual precipitations 1953-67 in Rio Santa Basin as a function of altitude. Safuna value is for 1968. Dashed lines connect stations on the same transverse line. 


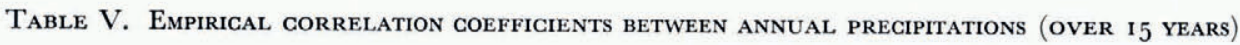

Station No. 4: Collota

$$
\text { Station } \mathcal{N o} \text {. }
$$

8: Shacaypampa

1 2: Huaraz

14: Yungay

16: Caraz

13: Chancos

15: Llanganuco(3)

17: Parón

18: Hidroelectra( $(\mathrm{r})$

\begin{tabular}{ccccc}
\multicolumn{5}{c}{ Callejón de Huaylas } \\
4 & \multicolumn{1}{c}{8} & \multicolumn{1}{c}{ I 2} & \multicolumn{1}{c}{ 14 } & \multicolumn{1}{c}{ 16 } \\
$\mathbf{1 . 0 0 0}$ & $\mathbf{0 . 7 2 1}$ & $\mathbf{0 . 7 5 9}$ & $\mathbf{0 . 5 9 5}$ & $\mathbf{0 . 4 9 3}$ \\
$\mathbf{0 . 7 2 1}$ & $\mathbf{1 . 0 0 0}$ & $\mathbf{0 . 8 6 0}$ & $\mathbf{0 . 5 6 9}$ & 0.291 \\
$\mathbf{0 . 7 5 9}$ & $\mathbf{0 . 8 6 0}$ & $\mathbf{1 . 0 0 0}$ & $\mathbf{0 . 6 5 4}$ & $\mathbf{0 . 4 7 0}$ \\
$\mathbf{0 . 5 9 5}$ & $\mathbf{0 . 5 6 9}$ & $\mathbf{0 . 6 5 4}$ & $\mathbf{1 . 0 0 0}$ & $\mathbf{0 . 6 7 2}$ \\
$\mathbf{0 . 4 9 3}$ & 0.291 & $\mathbf{0 . 4 7 0}$ & $\mathbf{0 . 6 7 2}$ & $\mathbf{1 . 0 0 0}$ \\
0.350 & $\mathbf{0 . 5 3 6}$ & $\mathbf{0 . 4 2 1}$ & $\mathbf{0 . 4 7 8}$ & -0.008 \\
0.414 & 0.427 & 0.382 & -0.083 & -0.061 \\
0.124 & 0.032 & 0.182 & $\mathbf{0 . 2 7 6}$ & $\mathbf{0 . 6 6 9}$ \\
0.304 & 0.215 & 0.308 & 0.134 & 0.140
\end{tabular}

\begin{tabular}{rrrc}
\multicolumn{5}{c}{ Cordillera } & Blanca \\
13 & $15^{(3)}$ & \multicolumn{1}{c}{17} & $18^{(1)}$ \\
0.350 & 0.414 & 0.124 & 0.304 \\
$\mathbf{0 . 5 3 6}$ & 0.427 & $0.03^{2}$ & 0.215 \\
$0.4^{21}$ & $0.3^{8} 2$ & 0.182 & 0.308 \\
$\mathbf{0 . 4 7 8}$ & -0.083 & 0.276 & 0.134 \\
-0.008 & -0.061 & $\mathbf{0 . 6 6 9}$ & 0.140 \\
$\mathbf{1 . 0 0 0}$ & 0.336 & -0.102 & 0.235 \\
0.336 & $\mathbf{1 . 0 0 0}$ & 0.294 & 0.163 \\
-0.102 & 0.294 & $\mathbf{1 . 0 0 0}$ & 0.346 \\
0.235 & 0.163 & 0.346 & $\mathbf{1 . 0 0 0}$
\end{tabular}

(1) over 14 years; (3) over 12 years.

Bold-faced figures: assuming a normal distribution, and according to the $t$-test there is less than $10 \%$ probability that this correlation comes by chance.

Figures in italics: there is more than $50 \%$ probability that this correlation comes by chance.

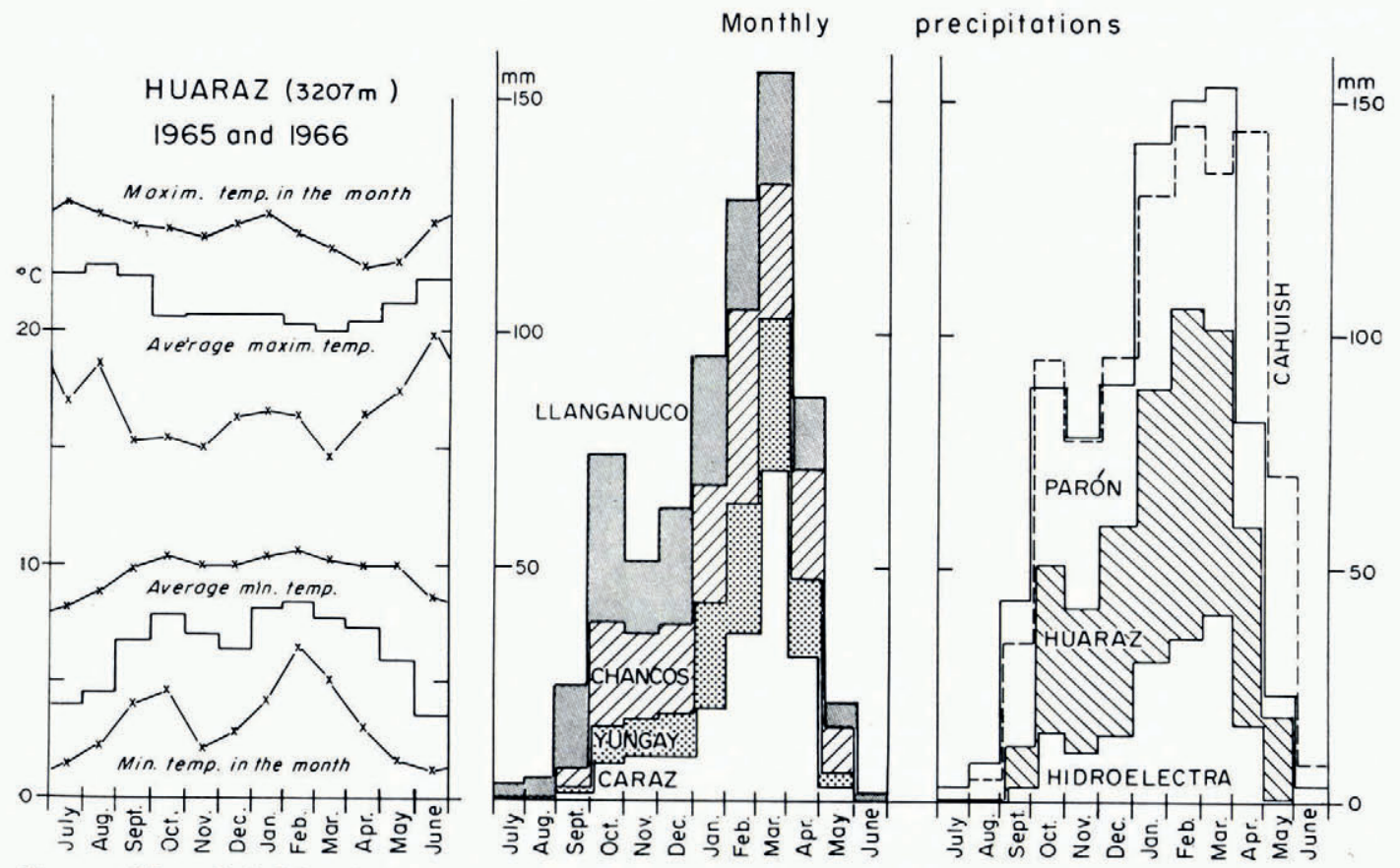

Fig. Io. Meteorological data for Cordillera Blanca and Callejón de Huaylas. Note that July has been taken as the first month.

The air temperature should vary more regularly than rain from one site to another, and thus the data from Huaraz (Fig. Io) are typical of the whole area, taking into account a temperature gradient of $0.73 \mathrm{deg} / \mathrm{I} 00 \mathrm{~m}$. The seasonal fluctuations of maximum temperatures is insignificant. The minimum temperatures are higher during the rainy season than during the dry one; in March their range is only about $5 \mathrm{deg}$. Thus the snow turns into rain at almost the same altitude all the year round.

This fact and the high value of the activity coefficient makes the glaciers of Cordillera Blanca much more sensitive to secular variations in temperature than to secular variations in precipitation. Thus old glacier advances can be related to a lowering of the mean air temperature over equatorial regions rather than to a shift of the path of atmospheric perturbations (as in semi-arid Chile for instance). Old glaciations in Peru, if they were accurately dated, would provide a straightforward and crucial test for theories about the origin of ice ages. 


\section{Glacial geology of Cordillera Blanca}

Let us sketch briefly the geological facts concerning the upper Cenozoic and Pleistocene (Aubouin and others, I973; Lliboutry and others, unpublished).

The granodiorite batholith of Cordillera Blanca was formed about seven million years ago. During the Pliocene, intensive volcanism formed Cordillera Negra, and both Cordilleras began uplifting at a rate not less than $2000 \mathrm{~m}$ per million years. This upheaval is still going on at the scale of one thousand years. Callejón de Huaylas uplifted too, by about $3000 \mathrm{~m}$ in total, but at a lesser rate, and thus acquired its actual aspect of being a graben.

There were many catastrophic events. At Huaraz, Tertiary lavas are overlain by volcanic breccias, and next by nine successive layers of heterometric detritic material consolidated by salts. Nevertheless more to the north erosion by Rio Santa was preponderant. At Malpaso (just north of Carhuás), within a fluvial terrace cut by Rio Buín an old moraine of the Pleistocene can be seen, which lies directly on the Chimú formation (sandstones and quartzites of the Jurassic-Cretaceous boundary).

Owing to the continuous uplift of Cordillera Blanca, the last great glaciation of the Pleistocene was the largest one. Glaciers flowed down to the Callejón de Huaylas and blocked the valley at several places, with the formation of kame terraces. Such was the case for instance at Malpaso $(2650 \mathrm{~m})$ : the glacier tongue probably did not come from Quebrada de Ulta (whence Rio Buín flows), but from Quebrada Hualcán further up-valley, which is shorter. At Huaraz a very old moraine is found at $3100 \mathrm{~m}$ (denoted $\mathrm{m}_{\mathrm{I}}$ on the map, Fig. I I ).

The more accessible moraines, already pointed out by Kinzl (1942), are found above Huaraz, on the way to Laguna Llaca. They were incidentally studied by Michel Vallon in the aforementioned unpublished report. He distinguishes two neat moraines $\mathrm{m}_{2}$ and $\mathrm{m}_{3}$, formed by narrow glacier tongues which were deviated to the right $\left(\mathrm{m}_{3}\right.$ more than $\left.\mathrm{m}_{2}\right)$ and a smooth morainic arc which ends at about $3400 \mathrm{~m}, 9 \mathrm{~km}$ from Laguna Llaca. He thinks that $m_{4}$ was younger than $m_{2}$ and $m_{3}$, but we think the reverse. There should be, after the formation of $\mathrm{m}_{4}$, an important upheaval of Cordillera Blanca, allowing fluvial erosion. The small valley so created, which bends towards the right, canalized the subsequent glacier advances.

We cross next the great Cordillera Blanca Fault and enter into Quebrada Llaca. At this point, at about $3900 \mathrm{~m}$ and $6 \mathrm{~km}$ from Laguna Llaca there is a single outer morainic arc $\mathrm{m}_{5}$, and several faint inner ridges denoted $\mathrm{m}_{6}$. The whole has been cross-cut by the almost vertical fault, denoting a vertical relative uplift of about $10 \mathrm{~m}$. Assuming that the difference of uplift rates between the batholith and Callejón de Huaylas has been 1.5 to $2 \mathrm{~m}$ per thousand years, this morainic system should be 5 ooo to 7 ooo years old.

Lastly there are two young morainic arcs $1.2 \mathrm{~km}$ apart: $\mathrm{m}_{7}$ at $4300 \mathrm{~m}$ and $\mathrm{m}_{8}$ around Laguna Llaca, the level of which is $4460 \mathrm{~m}$.

At Safuna we have described the two old moraines I and II around Safuna Baja, moraine III crossing this lake, half-buried moraine IV, the big push moraine V (obviously formed during the last Little Ice Age), and small moraine VI of the twentieth century advance. At least two older moraines can be seen down-valley: one at Huilcapampa (3 970 m) which extends towards Safuna on the right side of the valley, and another one forming a terrace at great height on the left side (Fig. I). The front of this last one must lie somewhere much further down-valley.

On the west side of Pucahirca, at the bottom of Tayapampa, there exist two lakes, Pucacocha and Laguna Kaico, which correspond exactly to Safuna Alta and Safuna Baja. Laguna Kaico is also crossed by a moraine III.

In other places the moraines can be quite different. As said in Lliboutry (1977), the big Hatunraju moraine in front of Laguna Parón should result from the superimposition of all the moraines, I to VI, which are separated at Safuna. On the southern side of Uraushraju 


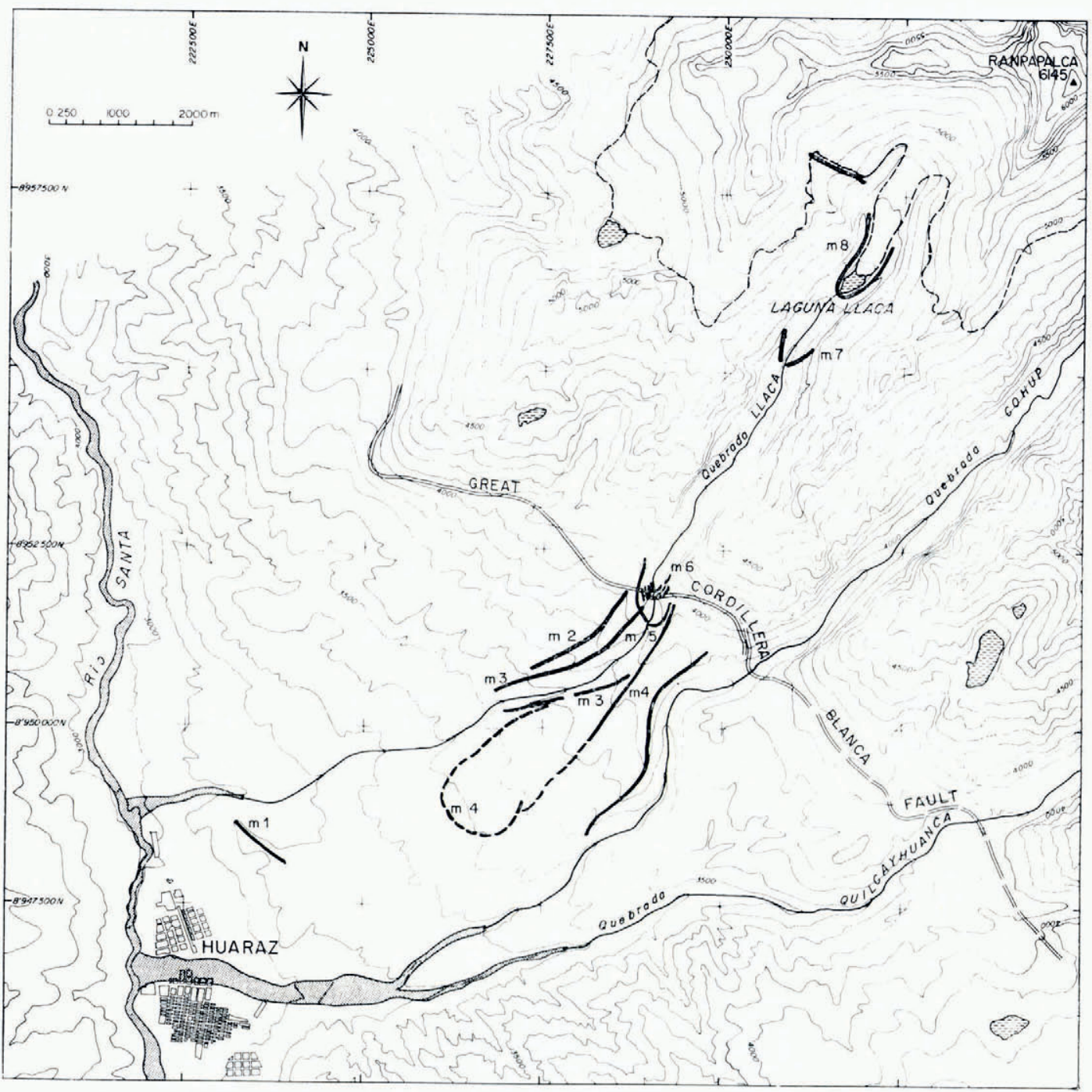

Fig. II. Moraines between Huaraz and Laguna Llaca, according to M. Vallon (Lliboutry and others, unpublished).

Tabke VI. Suggested correlation between moraines over Huaraz and at SAFUNA

\begin{tabular}{|c|c|c|c|c|}
\hline \multicolumn{2}{|c|}{ Clapperton $(1.972)$} & \multicolumn{3}{|c|}{ This study } \\
\hline Group & Age & Safuna & Huaraz & Age \\
\hline \multirow{3}{*}{4} & Twentioth sonts & VI & & Twentieth century \\
\hline & & V & $\mathrm{m}_{8}$ & Seventeenth century \\
\hline & & $\begin{array}{l}\text { IV } \\
\text { III }\end{array}$ & $\mathrm{m}_{7}$ & \\
\hline 3 & A.D. $175^{\circ}-1800$ & I-II & $m_{5}-m_{6}$ & 5 oOo to 7000 B.P. \\
\hline $\begin{array}{l}2 \\
1\end{array}$ & $\begin{array}{c}4000 \text { to } 6 \text { ooo B.P. } \\
\text { Wisconsin }\end{array}$ & Huilcapampa & $m_{2}-m_{3}$ & Late glacial \\
\hline & Wisconsin & Upper terrace & $\mathrm{m}_{1}-\mathrm{m}_{4}$ & \\
\hline
\end{tabular}


(south-east from Huaraz, see location on Fig. 8) there is a young moraine close to the glacier and next four morainic arcs on a flat area at $4000 \mathrm{~m}$ distant respectively 6,9 , I0 and $\mathrm{I} 2 \mathrm{~km}$ from the glacier.

We shall end these indications for future research workers by suggesting a correlation between the morainic systems at Huaraz and Safuna, and a chronology which makes them much older than assumed by Clapperton (1972) (Table VI).

\section{AGKnowledgments}

All this work in Peru could not have been done without the effective support of many engineers and technicians of Corporación Peruana del Santa (now Electroperú, Section V). Let us thank specially its technical Director Ing. Del Carpio, Ing. Galvez who organized the topographical work and Ing. Rossell who recollected the meteorological data. Thanks are given to its director, who in 1970 allowed the publication of the results. We have already quoted the distinguished work done by Servicio Aerofotográfico Nacional, by Ing. J. Arce, and by the chief of the diving department of the Navy at Callao, First Lieutenant Jeanneau.

MS. received 21 Fune 1976

\section{REFERENGES}

Ames, A. 1969. Control topográfico del movimiento glaciar en el Pucahirca Norte y el Uruashraju. Revista Peruana de Andinismo y Glaciología, 1966-67-68, No. 8, p. 1 I 7-18.

Arce Helberg, J. Unpublished. Proyecto Safuna. Estudio geofísico, diciembre r967.-Estudio geofísico complementario, marzo ig68. [Two reports to Corporación Peruana del Santa.]

Aubouin, J., and others. 1973. La Cordillère des Andes, par J. Auboin et [26 autres]. Revue de Géographie Physique et de Géologie Dynamique, Vol. ${ }_{1} 5$, Fasc. 1-2, p. $5^{-2}$ I 6.

Clapperton, C. C. 1972. The Pleistocene moraine stages of west-central Peru. Journal of Glaciology, Vol. I I, No. 62 , p. $255-63$.

Coyne et Bellier, Géoconseil. Unpublished [a]. Laguna Safuna. Informe sobre les reconocimientos. [Final report to Corporación Peruana del Santa, November ig69.]

Coyne et Bellier, Géoconseil. Unpublished [b]. Lagunas de Safuna. Informe de la misión de Julio de 1967. [Preliminary report to Corporación Peruana del Santa, ig67.]

Kinzl, H. 1942. Gletscherkundliche Begleitworte zur Karte der Cordillera Blanca (Peru). Zeitschrift für Gletscherkunde, Bd. 28, Ht. I-2, p. I-19.

Llibjutry, L. A. 1977. Glaciological problems set by the control of dangerous lakes in Cordillera Blanca, Peru. II. Movement of a covered glacier embedded within a rock glacier. Journal of Glaciology, Vol. 18, No. 79,

p. $255-73$.
Lliboutry, L. A., and others. 1977. Glaciological problems set by the control of dangerous lakes in Cordillera Blanca, Peru. I. Historical failures of morainic dams, their causes and prevention, by L. [A.] Lliboutry, B. Morales Arnao, A. Pautre and B. Schneider. Journal of Glaciology, Vol. 18, No. 79, p. 239-54.

Lliboutry, L. A., and others. Unpublished. Evaluación de los riesgos telúricos en el Callejón de Huaylas, con vista a la reubicación de poblaciones y obras públicas, [by] L. [A.] Lliboutry, V. Mencl, B. Schneider, M. Vallon. [UNESCO report No. 2208 BMS-RD/SCE, Paris, 1970.]

Morales Arnao, B. I969[a]. Estudio de la evolución de la lengua glaciar del Pucahirca y de la Laguna Safuna. Revista Peruana de Andinismo y Glaciología, I 966-67-68, No. 8, p. 89-96.

Morales Arnao, B. 1969 [b]. Estudios de ablación en la Cordillera Blanca. Revista Peruana de Andinismo y Glaciología, $1966-67-68$, No. 8, p. I $11-16$.

Reynaud, L. 1975. Mouvements du glacier en surface sur une courte échelle de temps. Hydrological Sciences Bulletin, Vol. 20, No. 3, p. 329-39.

Schneider, B. I969. Levantamiento de batimetría en la Cordillera Blanca. Revista Peruana de Andinismo $y$ Glaciología, 1966-67-68, No. 8, p. 67-75.

Viollet-le-Duc, E. 1876. Le Massif du Mont-Blanc, étude sur sa constitution géodésique et géologique, sur ses transformations et sur l'état ancien et moderne de ses glaciers. Paris, Librairie Polytechnique J. Baudry. 